CHRISTY EMILIO IOANNIDOU

The Association of Historical Studies

KORYVANTES

Athens, Greece

E-mail:perialos1@gmail.com
Received: October $24^{\text {th }} 2021$

Accepted: November $20^{\text {th }} 2021$

Original research article

904:629.5"652"(38)

COBISS.SR-ID 55449609

https://doi.org/10.18485/arhe_apn.2021.17.1

\title{
THE HARD TASKS OF KELEUSTẼS IN ANCIENT GREEK TRIREMES
}

\begin{abstract}
The rank of keleustēs in ancient Greek triremes is of great interest as it does not appear to be restricted to maintaining the rhythm of rowing through loud commands. Even if the above role represented hard work with many difficulties during naval battles, tasks such as chanting prayers to the Gods before battle or the provision of bread, wine and meat to rowers also came under his authority.
\end{abstract}

\section{KEYWORDS: KELEUSTĒS, COMMANDS, ORDERS, ROWING RHYTHM.}

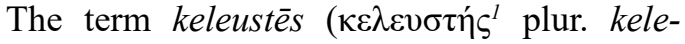
ustai) derives from the ancient Greek verb keleuo

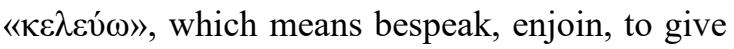
the command to rowers to keep the rowing rhythm (Stamatakos 1999, Ioannidou 2014).

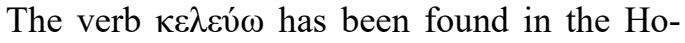
meric epics in the general sense of bespeak, command (e.g. servants, soldiers, etc.). In the marine

1 The ancient term exist today in Hellenic Navy corresponding to Petty Officer. environment we see it as an imperative for various naval operations (such as setting the sails, embarkation of the crew) and not with the meaning of words and phrases recited to achieve a rate of rowing (Hom. Il. 2. 151, Od., 2. 422-423, 9. 560). The term keleustēs is subsequent to the Homeric epics. As regards to the first depiction whereby it is clearly distinguished the attitude and position of keleustēs, we could say that it comes from an

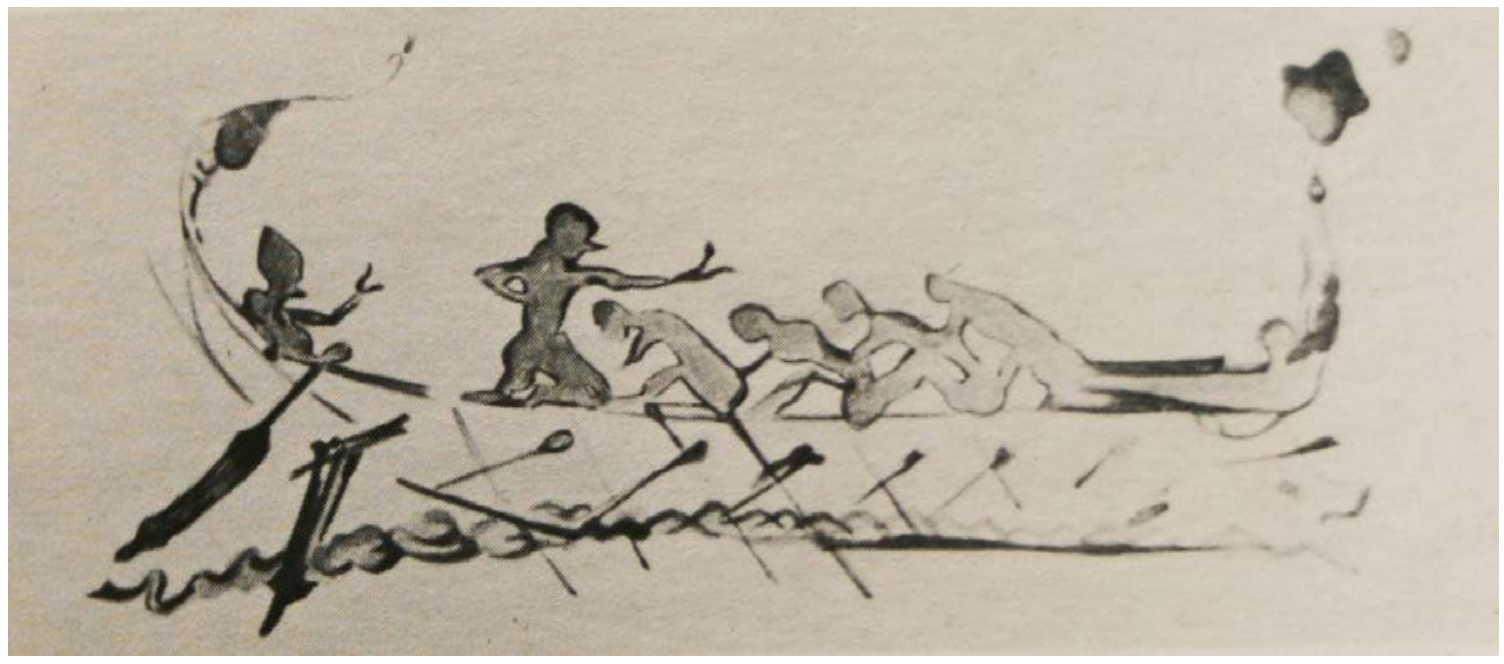

Plate 1. Aryballos of Corinthian style (550 BC). National Archaeological Museum, No. 281. 


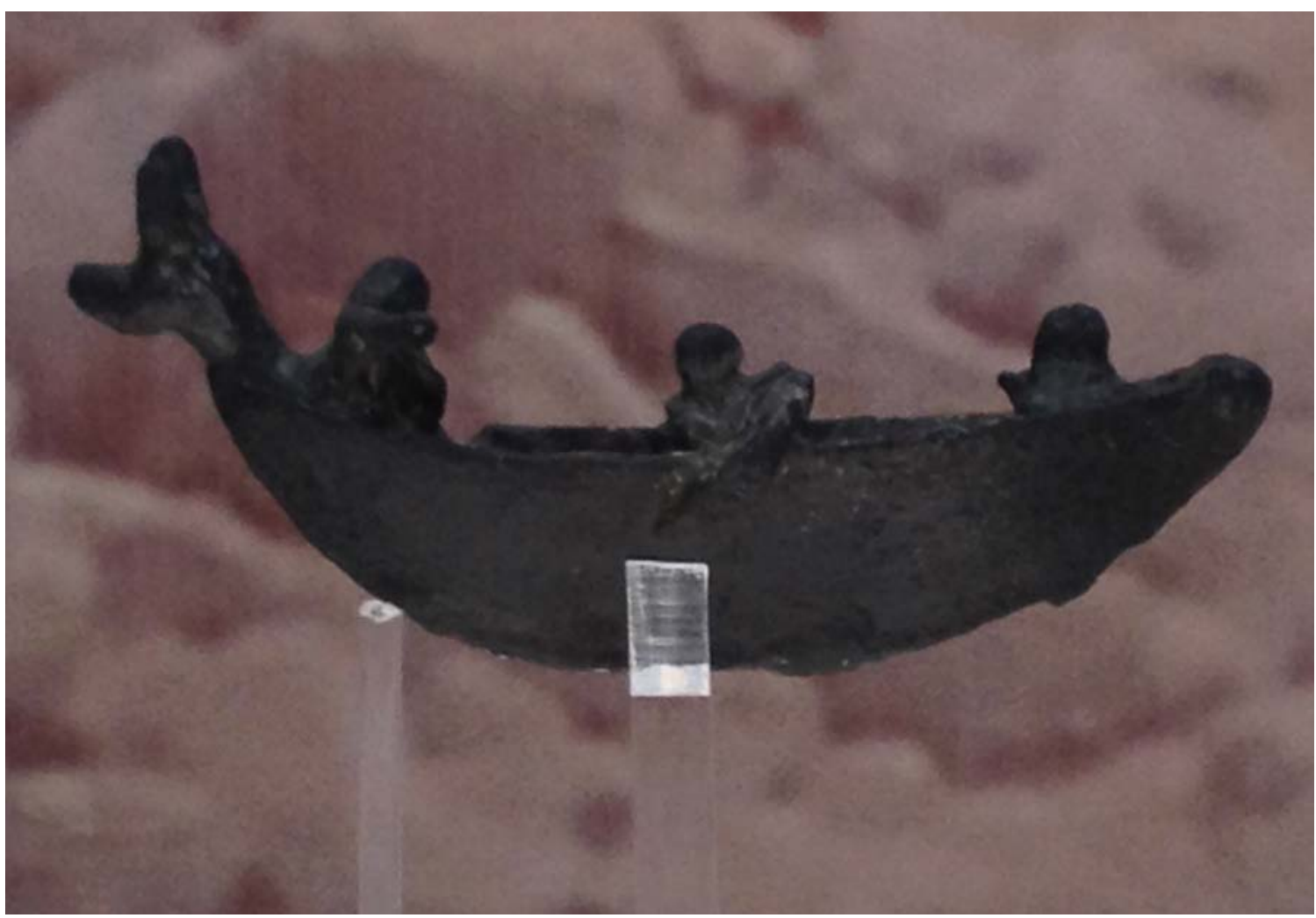

Plate 2. Bronze model boat with passengers, 6th century B.C., Archaeological Museum of Isthmian, 39 IM 2090. Photo: C.E. Ioannidou.

aryballos ${ }^{2}$ of the $6^{\text {th }} \mathrm{BC}$ century (plate 1 ).

To maintain 170 rowers, a level of oarsmanship was necessary and, among other things, the keleustēs had to be a person worthy of respect and had to possess skills to inspire the crew. This was made clear by Xenophon, who separate the capable keleustēs from the incapable one. In the first case the voyage would take place in the designated time and relatively pleasantly, as the crew endured their labours willingly and with pride. In the second case the voyage would be undertaken in twice the time with unpleasant feelings, particularly among the keleustēs and the crew (Xen. Oec. XXI 3-4).

In ancient texts there is an impression that commands were not limited to simple dictates but were given following a rhythm or were sung like songs (Luc. Catapl. 641-642, 19). This could be achieved if a word or a short phrase followed the same tone and was repeated at a specific time.

2 A small flask with wide base and narrow neck. It was used to contain perfume or oil. It was elegant and decorated with paintings.
Such commands are well known in Aristophane's Frogs (209-269).

Often there was another crew member, the pip-

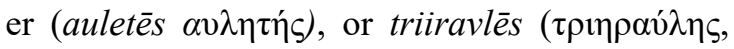
$\tau \rho \imath \rho^{\prime} \eta_{S}+\alpha \hat{v} \lambda \dot{\varepsilon}(\omega)$, who accompanied the keleustês with melodies on his pipe (Ioannidou 2014).

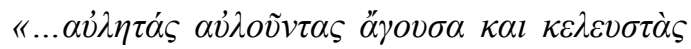

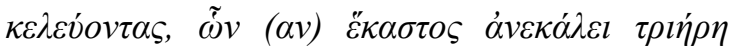

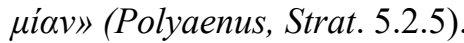

[...carrying pipers playing music and keleustai who had given orders, each of which invited a trireme].

Sometimes the position of keleustēs could be filled by a person who was already a known artist of his time. For example, the famous actor of Greek tragedies Callippides, rode on the brilliant trireme of Alcibiades, at the time when the Athenian general made the Athenians rulers at Hellespont after the successful Battle of Cyzicus $410 \mathrm{BC}$, and was returning to Athens. Callippides, with his songs, gave the commands to the oars- 
men while the auletēs Chrysogonos, who was also a celebrated victor in the piper competition at Delphi, played on a flute the trieric air (Ath.12, 535d, Plut. Alc. 32).

One of the oldest depictions of a piper on a ship comes from a bronze model boat with passengers, from the $6^{\text {th }}$ century. B.C., located in the Museum of Isthmia (plate 2).

As is well known, slaves were often used in triremes too. Thucydides (Thuc7.13.2) noted that desertion by a slave serving in the trireme was a possibility and that it was the duty of the slave's master to prevent it. Plenty of names in inscriptions testify that slaves were members of crews on triremes as rowers or as the personal servants of the officers and marines, carrying out duties on the same or on a different trireme to their masters (Graham 1998, 98-102). Among these slaves were also pipers. We have interesting information that Phormio, a slave of Dio of Phrearrii, was a trireme piper, a "triiravlēs" (Dem. De cor. 129-130).

\section{THE ISSUE OF COMMUNICATION WITHIN THE SHIP}

Whether the keleustēs had to be "sweet-voiced" or not is not known. Although from the ancient texts its quite easy to assume that a loud and clear voice would have been a basic requirement.

From the writings of Diodorus Siculus we derive the information that before the battle of Salamis in Cyprus (306 BC), when both warring ships completed their formations, they prayed to the gods through the keleustai (Diod. Sic. 20,50,6), while the crew participated by joining its voice to theirs. The words in the ancient text of Diodorus: $\kappa \alpha \theta \dot{\alpha} \pi \varepsilon \rho \tilde{\eta} v \ddot{\varepsilon} \theta o \varsigma$ (ie as customary), leads us to the thought that it was common for keleustai to chant prayers to the Gods before a battle, it is not known, however, when chronologically this started.

The chant of the keleustês is also praised in a Greek novel of early Christian times, Daphnis and Chloe. Despite the fact that the specific descrip- tion concerns a fishing vessel and not a warship, Longus describes vividly a scene where the vessel was crossing the sea and the voice of the keleustēs singing nautical songs was heard with so much pleasure, while the rest of the crew, like a chorus, sang out in unison to the time of his voice. However, before this romantic description, Longus makes it clear that the weather conditions were very favourable for a crew to hear the keleustês clearly:

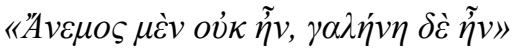

[There was no wind but a dead calm] (Longus, Daphnis and Chloe, 3, 21, 2).

In difficult situations the task of keleustēs would become harder, as he had to give orders, for example, during a noisy naval battle. The noise created by the impact of the wooden ships, the cries of the wounded, the enemy's commands or the loud insults ${ }^{3}$ of warriors would all stifle the commands. This could compromise the ideal picture of the keleustēs as he would be forced to issue his orders with screams rather than in a song:

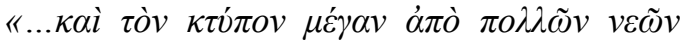

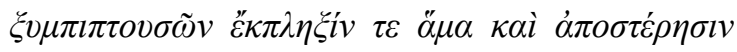

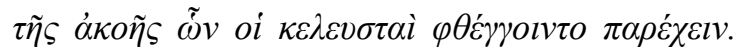

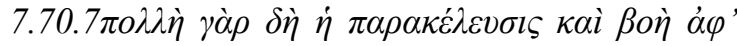

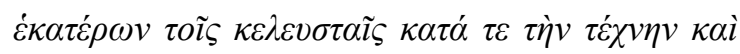

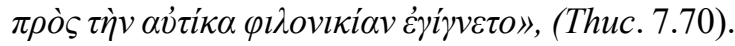

[...while the huge din caused by the number of ships crashing together not only spread terror, but made the orders of the boatswains inaudible. The boatswains on either side in the discharge of their duty and in the heat of the conflict shouted incessantly orders and appeals to their men;].

If, in these critical moments, he could not achieve his task then disorder in the fleet would follow as the rowers would be unable to hear or even understand who was giving orders and the ships would be more difficult for the crew to handle (Thuc. 2.84).

On the other hand, in cases where rowing near the enemy was to be done in secret, such as, for

3 It was customary before or during a battle for combatants to exchange insults, in writing or orally. C.E. Ioannidou, 2017. 
example, during the night, the oarsmen turned the oars lightly and the keleustēs held the rhythm by tapping stones instead of by using their voice.

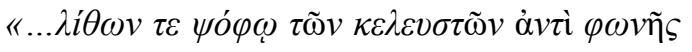

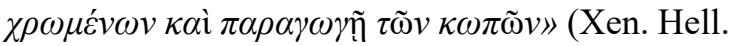
5.1, 8-9).

[In place of the usual cry the boatswains timed the rowers by a clink of stones, and silently the oars slid].

.. There are also two interesting accounts of a keleustēs' total silence in Arrian's texts:

The first one as a consequence of calm rowing before the battle:

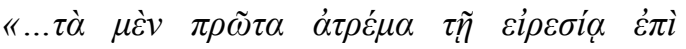

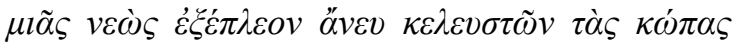

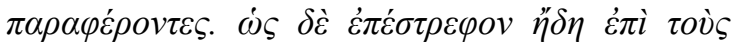

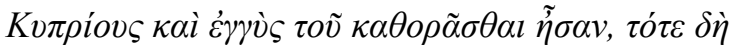
$\xi \grave{v} v \beta o \tilde{\eta} \tau \varepsilon \pi o \lambda \lambda \tilde{\eta} \kappa \alpha \dot{\imath} \dot{\varepsilon} \gamma \kappa \varepsilon \lambda \varepsilon v \sigma \mu \tilde{\varphi} \dot{\varepsilon} \varsigma \dot{\alpha} \lambda \lambda \dot{\eta} \lambda o v \varsigma \kappa \alpha \grave{l}$

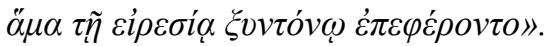

"At first they rowed out slowly and quietly in single file, moving forward the handles of their oars without any signal from the men who give the time to the rowers; but when they were already tacking against the Cyprians, and were near enough to be seen, then indeed with a loud shout and encouragement to each other, and at the same time with impetuous rowing, they commenced the attack" (Arr. Anab. 2.21).

The second one as a result of a loud environment and of great surprise near the region of the confluence of the rivers Hydaspes and Acesines:

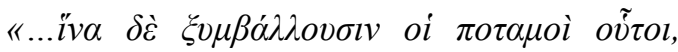

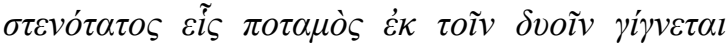

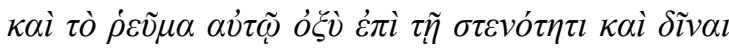

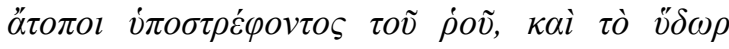

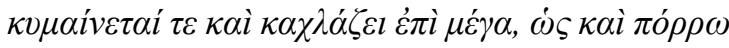

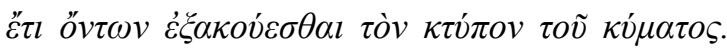

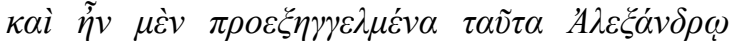

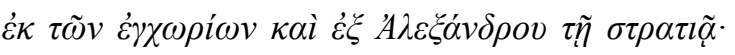

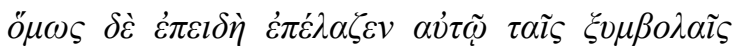

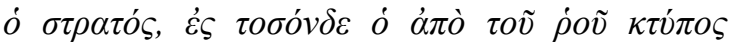

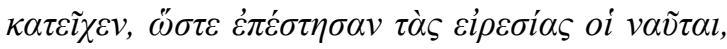

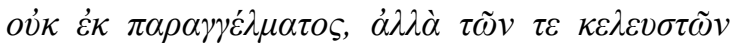

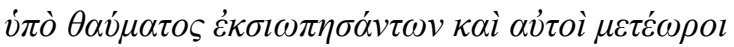

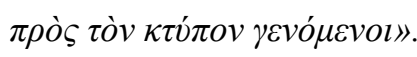

"... one very narrow river is formed out of the two; and on account of its narrowness the current is swift. "There are also prodigious eddies in the whirling stream, and the water rises in waves and plashes exceedingly, so that the noise of the swell of waters is distinctly heard by people while they are still far off. These things had previously been reported to Alexander by the natives, and he had told his soldiers; and yet, when his army approached the junction of the rivers, the noise made by the stream produced so great an impression upon them that the sailors stopped rowing, not from any word of command, but because the very keleustai who gave the time to the rowers became silent from astonishment and stood aghast at the noise" (Arr. Anab. 6,4).

So, it comes to our attention that in good weather conditions the voice of the keleustēs and the sound of the pipe will be more than enough to be heard by all the oarsmen. Could that be true?

When considering the trials carried out in the trireme Olympias we can be lead to some conclusions. During the first two years of the trials (1987-1988), the keleustēs found it difficult to be heard throughout the ship, even when using a powered megaphone (Coates 1990, 17).

"The rowing master, acting under the captain, commanded and coached the crew with the help of a hand-held powered megaphone. He chose his position in the ship according to the direction of the wind so as to be as audible as possible to all sections of the oarcrew. Whenever it was thought helpful, the oarcrew chanted 'O-Op' to mark the catch and finish of strokes and so to bring the stroke together" (Coates 1990, 16).

In the following year the communication between the keleustēs and oarsmen was restored thanks to a microphone installed with six speakers. Adding a piper was equally important as the high-frequency sound of the flute could be heard throughout the ship. The location of piper was next to the sail, following the indications of the ancient texts, and allowed the keleustēs to concentrate 
solely on the guidance, while the oarsmen simultaneously followed the rhythm of known melodies (Rankov 2014, 134-135. Christopoulos 1996, 151).

"The complement of an ancient trireme including a piper auletes and it is quite possible that this pipe performed much the same function as the bosun's call in latter day naval ships as a means of broadcasting standardized orders. For much of the time during the second phase of these trials a piper indicated the timing of the stroke (the 'cadence'), and that helped greatly in keeping the oarcrew pulling together" (Coates 1990, 17).

Despite all of the above, it was quite difficult to find a way of giving the rhythm only by voice. Even if the position of the keleustês was stand-

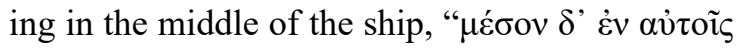

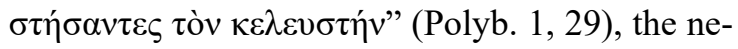
cessity of the auletēs seems imperative as well as the presence of a second keleustēs. However, do we have the presence of a second keleustēs in ancient triremes? According to most ancient inscriptions, as for example IG I3 1032 (List of crews of Athenian triremes ca 410-400BC), there were no more than one keleustēs or auletès in each trireme.

Regarding to Olympias trials, techniques for directing the oarsmen without electronic speakers are still being investigated (Rankov 2012, 3). Among others, a simple thought crossed our mind. Did people in ancient and classical times have better hearing than people today? This leaves an unanswered question in such a matter and space for further research.

\section{OTHER TASKS}

The keleustēs was the coach of the crew and responsible for their discipline. However, more than that he also had the responsibility for the proper provision of bread, wine and meat to the rowers and he gave orders to the marines (Suda, term $\kappa \varepsilon \lambda \varepsilon v \sigma \tau \dot{\text { c }}$, Arr. Parth. 61). Among other sources, an inscription from Delfi (IG VII-IX) CID 1.7. circa $425 \mathrm{BC}$ ) brings to light the above mentioned:

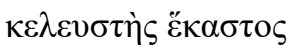

$\tau \omega v \delta \eta \mu \sigma \sigma^{-} v \mid \dot{\varepsilon} \rho \varepsilon \tau^{-} \omega v$. $\sigma \tilde{i}-$

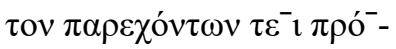

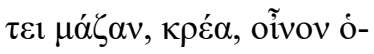

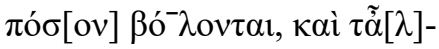

$\lambda \alpha \dot{\alpha} \rho \mu o ́ \delta 1 \alpha$.

Last but not least, his important role appears not only in the management of the warship. In a passage from the Xenophon we learn that the Keleustēs, with the rest of the hyperesia (naval service), are those who give the city its power:

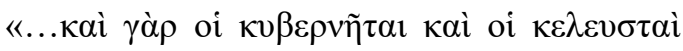

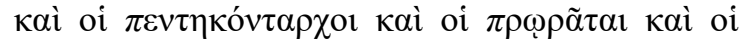

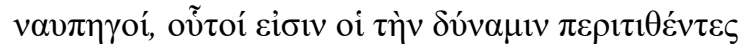

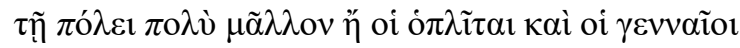

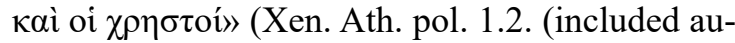
letes: IG II2, 1951, 94-105, GOS 266-8).

[The steersman, the keleustai, the lieutenant, the look-out-man at the prow, the ship carpenters these are the people who encompass the city with power far more than her heavy infantry and men of noble birth].

\section{BIBLIOGRAPHY}

\section{Basch, L. 1987}

Le muse imaginaire de la marine antique, Athens, Institute Hellenique pour la Préservation de la Tradition Nautique.

\section{Christopoulos, M. 1996}

"Kéleuste, Aulète, trieraulète, son musical et manoeuvres des bateaux", Tropis $I V$, 4st International Symposium on Ship Construction in Antiquity, Hellenic Institute for the Preservation of Nautical Tradition, pp. 145-158.

\section{Coates, J.F. et al., 1990}

The Trireme Trials, 1988, Oxford, Oxbow Books.

Gardiner R. and J. S. Morrison eds. 1995.

The Age of the Galley: Mediterranean Oared Vessels Since Pre-Classical Times. Conway's History 
of the Ship, Naval Institute Press, London.

\section{Graham, A.J. 1998}

"Thucydides 7.13.2 and the Crews of Athenian Triremes: An Addendum", Transactions of the American Philological Association (1974-), Johns Hopkins University Press, Vol 128, pp. 89-114.

Julii Pollucis, Onomasticon: Graece \& Latine, Amstelaedami, Ex officina Wetsteniana, 1706.

Ioannidou, Ch. E. 2014

Dictionary of Ancient Greek Naval Terms [in

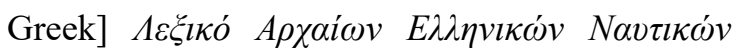
$O \rho \omega v$, Athens: Historical Quest.

Ioannidou, Ch. E. 2016

Trireme Tactic and Operational Environment in

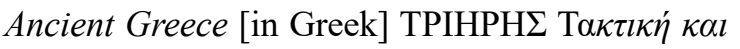

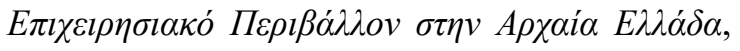
Athens: Naval History Department/Hellenic Navy.

Ioannidou, Ch. E. 2017

"Negative verbal symbols in ancient Greek warfare", (Joanna Popielska-Grzybowska \& Jadwiga Iwaszczuk (eds.) Thinking Symbols Interdisciplinary Studies, Acta Archaeologica Pultuskiensia, vol. VI, Publisher: Wydawnictwo Akademii Humanistycznej im. Aleksandra Gieysztora, pp.135-139.

Liddel H.G. \& R. Scott, 1985

A Greek-English Lexicon, rev. by H. Stuart Jones, Oxford.

\section{Morrison J.S. 1984}

"Hyperesia in Naval Contexts in the Fifth and Fourth Centuries BC", The Journal of Hellenic Studies, vol. 104, pp. 48-59.

\section{Rankov, B. 2014}

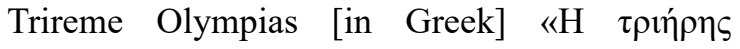

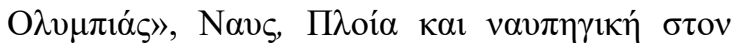

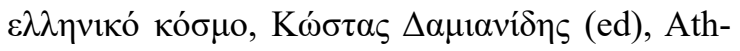
ens, Polaris.

\section{Rankov, B. 2012}

Trireme Olympias The Final Report, Sea Trials 1992-4, Conference Papers 1998, Oxford, Oxbow Books,

\section{Stamatakos, J. 1999}

Dictionary of Ancient Greek Language [in Greek],

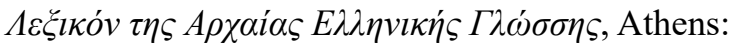

Vivliopromitheftiki.

\section{REZIME \\ TEŠKI ZADACI KELEUSTĒS-A U GRČKIM TRIJERAMA}

\section{KLJUČNE REČI: KELEUSTĒS, NAREDBE, RI- TAM VESLANJA, ANTIČKA GRČKA.}

Položaj keleustes-a u antičkim grčkim trijerama budi veliko interesovanje, budući da im nije jedini zadatak bio da održe ritam veslanja davanjem glasnih komandi. Iako im je pomenuta uloga bila teška tokom pomorskih bitaka, zadaci kao što je izgovaranje molitvi bogovima pre bitke ili deljenje hleba, vina i mesa veslačima takođe su bili deo njihove nadležnosti.

Arheologija i prirodne nauke (Archaeology and Science) is an Open Access Journal. All articles can be downloaded free of charge and used in accordance with the licence Creative Commons - Attribution-NonCommercial-NoDerivs 3.0 Serbia (https://creativecommons.org/licenses/bync-nd/3.0/rs/.

Časopis Arheologija i prirodne nauke je dostupan u režimu otvorenog pristupa. Članci objavljeni u časopisu mogu se besplatno preuzeti sa sajta i koristiti u skladu sa licencom Creative Commons - Autorstvo-Nekomercijalno-Bez prerada 3.0 Srbija (https://creativecommons.org/licenses/bync-nd/3.0/rs/. 